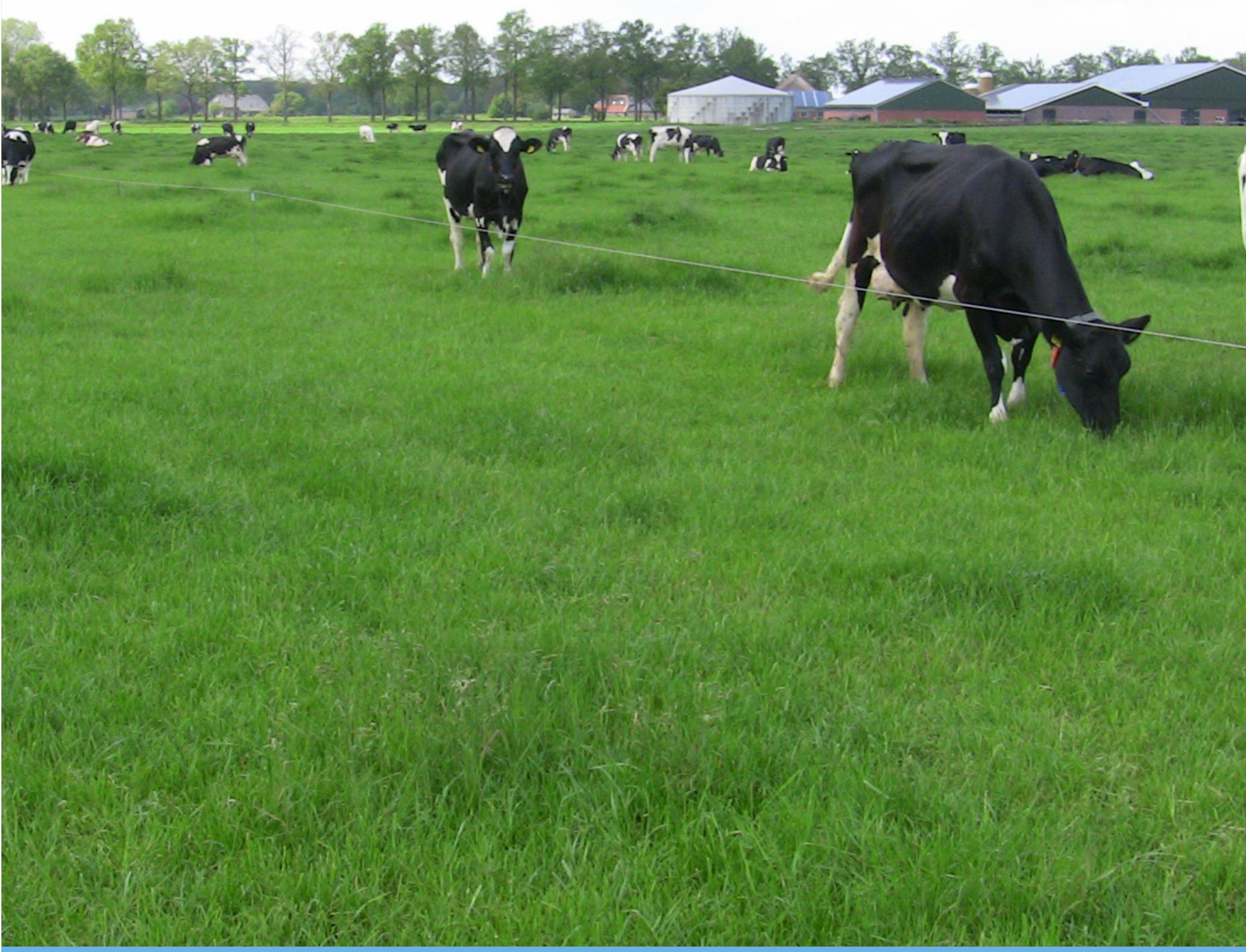

\title{
Verkenning betere berekening van opname vers gras in de KringloopWijzer
}





\section{Verkenning betere berekening van opname vers gras in de KringloopWijzer}

C.W. Klootwijk ${ }^{1}$, M.H.A. de Haan $^{1}$, A.P. Philipsen ${ }^{1}$ en A. van den Pol-van Dasselaar ${ }^{2}$

1 Wageningen Livestock Research, De Elst 1, 6700 AH Wageningen, Nederland

2 Aeres University of Applied Sciences, De Drieslag 4, 8251 JZ Dronten, Nederland

Dit onderzoek is uitgevoerd door Wageningen Livestock Research, in opdracht van en gefinancierd door ZuivelNL.

Wageningen Livestock Research

Wageningen, maart 2020

Rapport 1261 
Klootwijk, C.W., M.H.A. de Haan, A.P. Philipsen, A. van den Pol-van Dasselaar, 2020. Verkenning betere berekening van opname vers gras in de KringloopWijzer. Wageningen Livestock Research, Openbaar Rapport 1261.

Samenvatting NL. Dit onderzoek verkent mogelijkheden tot verbetering van de berekening van de opname van weidegras, met bijbehorende $\mathrm{N}$ - en P-gehalten, in de KringloopWijzer. Zowel resultaten van literatuuronderzoek als input van verschillende relevante stakeholders zijn gebruikt. Een daadwerkelijke verbetering vraagt om extra invoer, waarbij grootte van de huiskavel en periode van weidegang naar voren zijn gekomen als meest perspectiefvol.

Summary UK. This study explores options to improve the quantification of the on-farm fresh grass intake, and corresponding N and P content, in the ANCA tool (Annual Nutrient Cycling Assessment). Both literature and input from different relevant stakeholders were used. Additional data input is required to achieve an actual improvement. The size of the grazing platform and the period of grazing throughout the year appear to be the most promising options for this purpose.

Dit rapport is gratis te downloaden op https://doi.org/10.18174/524135 of op www.wur.nl/livestock-research (onder Wageningen Livestock Research publicaties).

\section{(C) 2020 Wageningen Livestock Research}

Postbus 338, 6700 AH Wageningen, T 03174839 53, E info.livestockresearch@wur.nl, www.wur.nl/livestock-research. Wageningen Livestock Research is onderdeel van Wageningen University \& Research.

Wageningen Livestock Research aanvaardt geen aansprakelijkheid voor eventuele schade voortvloeiend uit het gebruik van de resultaten van dit onderzoek of de toepassing van de adviezen.

Alle rechten voorbehouden. Niets uit deze uitgave mag worden vermenigvuldigd en/of openbaar gemaakt worden door middel van druk, fotokopie, microfilm of op welke wijze dan ook zonder voorafgaande toestemming van de uitgever of auteur.

Wageningen Livestock Research is NEN-EN-ISO 9001:2015 gecertificeerd.

Op al onze onderzoeksopdrachten zijn de Algemene Voorwaarden van de Animal Sciences Group van toepassing. Deze zijn gedeponeerd bij de Arrondissementsrechtbank Zwolle. 


\section{Inhoud}

Woord vooraf $\quad 5$

$\begin{array}{ll}\text { Samenvatting } & 7\end{array}$

1

$\begin{array}{ll}\text { Inleiding } & 9\end{array}$

1.1 Aanleiding $\quad 9$

1.2 Doel 9

2

$\begin{array}{ll}\text { Methode } & 10\end{array}$

$\begin{array}{lll}2.1 & \text { Literatuuronderzoek } & 10\end{array}$

2.2 Inventarisatie benaderingen nationale en internationale experts 10

$\begin{array}{ll}2.3 \text { Synthese } & 10\end{array}$

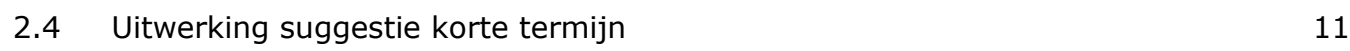

3

$\begin{array}{ll}\text { Literatuuroverzicht } & 12\end{array}$

3.1 Grasopname in de kringloopwijzer 12

3.2 Factoren van invloed op grasopname 13

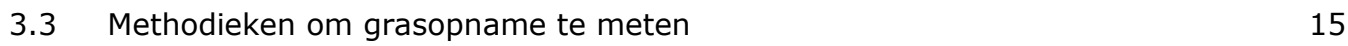

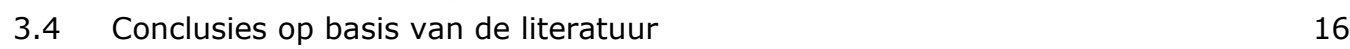

$\begin{array}{llr}\text { Inventarisatie benaderingen experts } & 17\end{array}$

$\begin{array}{lll}4.1 & \text { Mailconsultatie } & 17\end{array}$

$\begin{array}{llr}4.2 & \text { Workshop } & 18\end{array}$

$5 \quad$ Synthese op basis van literatuur en kennis van experts $\quad 22$

$6 \quad$ Uitwerking meest relevante suggesties voor de korte termijn 24

6.1 Grasopname 24

$\begin{array}{lll}6.2 & \text { Graskwaliteit } & 25\end{array}$

7 Conclusies en aanbevelingen $\quad 26$

$\begin{array}{ll}\text { Literatuur } & \mathbf{2 7}\end{array}$

Bijlage 1 Lijst met stakeholders die betrokken zijn bij dit project 29

Bijlage 2 Mail naar internationale experts 31

Bijlage $3 \quad$ Mail naar nationale experts 32 



\section{Woord vooraf}

De Nederlandse melkveehouderij maakt gebruik van het instrument KringloopWijzer om inzichtelijk te maken hoe de mineralen $\mathrm{N}$ en $\mathrm{P}$ door het bedrijf stromen en wat de milieuprestaties van het bedrijf zijn. De KringloopWijzer brengt de mineralenkringloop van een melkveebedrijf in kaart op basis van bedrijfsspecifieke gegevens. Op basis van de mineralenkringloop worden de $\mathrm{N}$ - en P-excreties berekend, de benutting van $\mathrm{N}$ en $\mathrm{P}$ in kaart gebracht en de emissies naar het milieu berekend. Met deze gegevens kan een veehouder zijn management optimaliseren en zo kosten besparen en de impact op het milieu verkleinen. Het invullen van de KringloopWijzer is sinds 1 januari 2016 verplicht gesteld door bijna alle zuivelverwerkers voor hun Nederlandse melkleveranciers, wat betekent dat bijna alle melkveebedrijven in Nederland (ong. 16.000) de KringloopWijzer jaarlijks moeten invullen. De melkveehouderij- en zuivelketen investeert via ZuiveINL in een centrale database en een correcte berekening van milieuprestaties met de KringloopWijzer. ZuivelNL is eigenaar van de Centrale Database KringloopWijzer (KLW) en samen met andere partijen verantwoordelijk voor de aansturing van de verdere wetenschappelijke doorontwikkeling van de KLW. De huidige werkwijze om grasopname, en bijbehorende gehalten, te berekenen leidt tot discussie in de praktijk, want de berekende grasopname wordt nogal eens als te hoog ervaren. Het doel van dit onderzoek was daarom om te verkennen of de opname van vers gras, met bijbehorende $\mathrm{N}$ - en P-gehalten, in de KringloopWijzer beter bepaald kan worden op basis van nieuwe inzichten uit onderzoek (literatuur, expertkennis, experimenten) dan de huidige werkwijze. In deze rapportage staan aanbevelingen om de opname van vers gras, met bijbehorende $\mathrm{N}$ - en P-gehalten, in de toekomst beter te kunnen bepalen. Het belang voor de melkveehouderij van dit onderzoek is uiteindelijk dat de berekening van de excreties en emissies in de KringloopWijzer verbeterd wordt, zodat melkveebedrijven ook beter hun emissies naar het milieu kunnen beperken. Dit is belangrijk voor de gehele melkveehouderijsector en rechtvaardigt daarom financiering door de ketenorganisatie ZuivelNL. Buiten de auteurs zijn er meerdere stakeholders betrokken geweest bij de in deze rapportage beschreven verkenning naar mogelijkheden om de grasopname, met bijbehorende $\mathrm{N}$ - en P-gehalten, beter te bepalen (zie bijlage 1).

Gert van Duinkerken, Wageningen Livestock Research 


\section{Samenvatting}

De Nederlandse melkveehouderij maakt gebruik van het instrument KringloopWijzer om inzichtelijk te maken hoe de mineralen $\mathrm{N}$ en $\mathrm{P}$ door het bedrijf stromen en wat de milieuprestaties van het bedrijf zijn. Daarnaast is behoud van weidegang een belangrijke doelstelling van de zuivelsector. De huidige werkwijze om grasopname, en bijbehorende gehalten, in de KringloopWijzer te berekenen leidt tot discussie in de praktijk. De berekende grasopname wordt nogal eens als te hoog ervaren. Momenteel berekent de KringloopWijzer de opname van het vers gras vanuit een formule, waarbij de koeien de eerste twee uur $1 \mathrm{~kg}$ droge stof (ds) vers gras (per uur) opnemen en de overige uren 0,75 kg ds vers gras. Vervolgens wordt deze hoeveelheid bijgesteld in een berekende verhouding met de verbruikte hoeveelheid graskuil en maiskuil (gemeten voorraden). De gehalten van $\mathrm{N}$ en $\mathrm{P}$ in het vers gras zijn afhankelijk gesteld van aangelegde graskuilen.

Het doel van dit onderzoek was om te verkennen of de opname van vers gras, met bijbehorende $\mathrm{N}$ - en P-gehalten, in de KringloopWijzer beter bepaald kan worden dan de huidige werkwijze. Om dit te verkennen is op basis van literatuuronderzoek en expertkennis een groslijst gemaakt van mogelijke benaderingen. De groslijst met benaderingen kon worden verdeeld in vier kwadranten. Kwadrant $A$ bevat benaderingen voor aanpassing van parameters in de huidige formules voor grasopname en kwaliteit. Kwadrant B1 bevat benaderingen voor aanpassing van de huidige formules voor grasopname en kwaliteit waarbij de parameters kunnen variëren voor verschillende type melkveebedrijven en waarbij de opzet van de formule ook aangepast kan worden. In dit kwadrant blijft de huidige invoer gelijk en zal alleen de formule aangepast worden. Kwadrant B2 bevat benaderingen voor aanpassing van de huidige formules op basis van (beperkte) extra invoer. Deze twee kwadranten zijn benaderingen voor de korte termijn. Kwadrant $C$ bevat benaderingen om extra metingen te doen op bedrijfsniveau en kwadrant $D$ bevat benaderingen om extra metingen te doen op een globaler niveau. Deze twee kwadranten zijn benaderingen voor de langere termijn. Vervolgens zijn de volgende zeven criteria opgesteld waar een benadering aan moet voldoen om toepasbaar te zijn voor de KringloopWijzer:

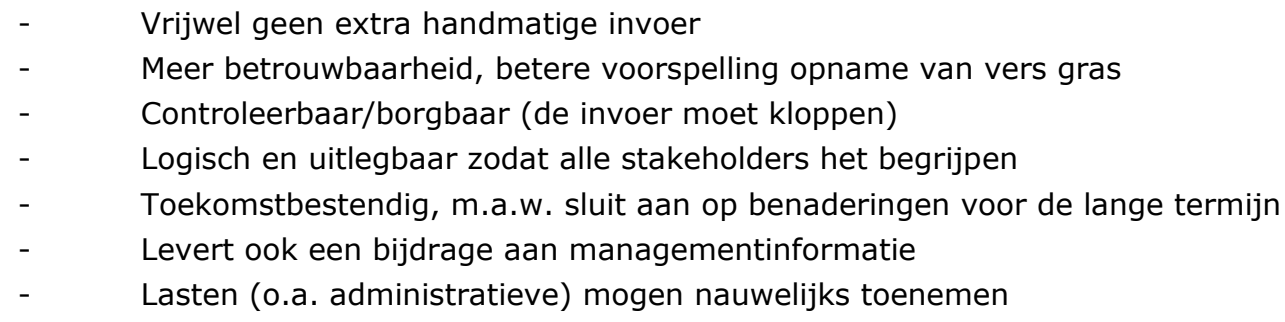

Op basis van deze criteria is met behulp van een matrix een shortlist gemaakt van perspectiefvolle benaderingen die besproken zijn in de stuurgroep "Wetenschappelijke doorontwikkeling KringloopWijzer' en in de klankbordgroep rondom de BEP-pilot. Uitgaande van uitsluitend de huidige invoer kan op basis van literatuuronderzoek en recente inzichten uit beweidingsonderzoek de berekening van de opname van vers gras, met bijbehorende N- en P-gehalten, in de KringloopWijzer niet verbeterd worden. Een daadwerkelijke verbetering vraagt om extra invoer, waarvoor meerdere benaderingen beschikbaar zijn. Voor de opname van vers gras is de grootte van de huiskavel in relatie tot het aantal weidende koeien (beweidingsintensiteit) naar voren gekomen als optie die inhoudelijk informatie geeft over het aanbod van vers gras per koe. Grootte van de huiskavel is redelijk makkelijk te registreren en ook objectief vast te stellen. Op basis van aanbod van vers gras kunnen experts een inschatting maken van de (maximale) grasopname per koe. De grasopname, maar zeker ook de graskwaliteit, verandert gedurende het seizoen. Het invoeren van de periode van weidegang zou de mogelijkheid kunnen bieden om onderscheid te maken tussen voorjaar, zomer en najaar. Ook dit kan tot een verbetering van de berekeningen leiden. Om de schatting van graskwaliteit verder te kunnen verbeteren is het zinvol om een database met graslandgegevens op basis van een meetnet met praktijkbedrijven te gaan onderhouden. 


\section{$1 \quad$ Inleiding}

\section{$1.1 \quad$ Aanleiding}

De Nederlandse melkveehouderij maakt gebruik van het instrument KringloopWijzer om inzichtelijk te maken hoe de mineralen $\mathrm{N}$ en $\mathrm{P}$ door het bedrijf stromen en wat de milieuprestaties van het bedrijf zijn. Daarnaast is behoud van weidegang een belangrijke doelstelling van de zuivelsector. Bijna alle Nederlandse melkveebedrijven, ongeveer 16.000, vullen jaarlijks verplicht de KringloopWijzer in om hun $\mathrm{N}$ en $\mathrm{P}$ efficiëntie te berekenen. Momenteel berekent de KringloopWijzer de opname van vers gras vanuit een formule, waarbij de koeien de eerste twee uur $1 \mathrm{~kg}$ droge stof (ds) vers gras (per uur) opnemen en de overige uren $0,75 \mathrm{~kg}$ ds vers gras. Vervolgens wordt deze hoeveelheid bijgesteld in een berekende verhouding met de verbruikte (gemeten voorraden) hoeveelheid graskuil en maiskuil. De gehalten van $\mathrm{N}$ en $\mathrm{P}$ in het vers gras zijn afhankelijk gesteld van aangelegde graskuilen. Deze werkwijze en de uitkomsten van deze berekening leiden tot discussie in de praktijk, want de berekende grasopname wordt nogal eens als te hoog ervaren. Het jaar 2018 was ook een goed voorbeeld van de beperkingen van het vaststellen van $\mathrm{N}$ en $\mathrm{P}$ gehaltes in vers gras op basis van aangelegde graskuilen. Door de droogte van 2018 zijn grasuilen vooral gemaakt in het voorjaar en najaar, met hoge stikstofgehalten. Dit leidt mogelijk tot een overschatting van de hoeveelheid stikstof in het vers gras. Daarnaast is voor bedrijven met een automatisch melksysteem het aantal uren weidegang sowieso moeilijk vast te stellen omdat de koeien niet op koppelniveau maar op individueel niveau naar binnen en naar buiten gaan. Het voordeel van de huidige benadering in de KringloopWijzer is overigens wel dat er, naast de uren en dagen weidegang, nauwelijks extra invoer nodig is.

\subsection{Doel}

Het doel van dit onderzoek is om te verkennen of de berekening van de opname van vers gras, met bijbehorende $\mathrm{N}$ - en P-gehalten, in de KringloopWijzer op basis van nieuwe inzichten uit onderzoek (literatuur, expertkennis, experimenten) beter bepaald kan worden. Hierbij is het gewenst dat er geen extra invoer van de melkveehouder nodig is. Belangrijk aandachtspunt bij eventuele extra invoer in de KringloopWijzer is dat deze invoer minimaal zo goed 'geborgd' is als in de huidige situatie en bij voorkeur automatisch in te lezen is, zonder subjectieve inschattingen van de melkveehouder. Dit onderzoek betreft vooral een kwalitatieve inventarisatie van mogelijke benaderingen om de opname en gehaltes van vers gras in beeld te brengen, van daadwerkelijke validatie is nog geen sprake. Wel wordt, naast de inventarisatie met benaderingen voor onderzoek op de middellange en lange termijn, één benadering uitgewerkt voor de korte termijn. Voor aanvang van het onderzoek is de verwachting uitgesproken dat de mogelijkheden om de vers grasopname beter in te schatten kansrijker zullen zijn dan de mogelijkheden om de bijbehorende gehalten goed in te schatten. 


\section{Methode}

\subsection{Literatuuronderzoek}

Om inzicht te krijgen in benaderingen om de grasopname, met bijbehorende $\mathrm{N}$ - en $\mathrm{P}$-gehalten, beter in te schatten in de KringloopWijzer is gestart met een inventarisatiefase op basis van literatuur. Hierin zijn ook benaderingen voor onderzoek op de middellange en lange termijn meegenomen. Omtrent de literatuur is eerst gekeken naar beschikbare methoden om de vers grasopname, met bijbehorende $\mathrm{N}$ - en P-gehalten, in kaart te brengen. Hiervoor zijn we begonnen met de herkomst en de achtergrond van de huidige grasopname formule. Vervolgens is gekeken naar Nederlandse rapporten over de KringloopWijzer. Daarna is op basis van internationale wetenschappelijke literatuur een overzicht gemaakt van hoe grasopname, en bijbehorende N- en P-gehalten, wordt beïnvloed en kan worden gemeten. In totaal zijn 318 wetenschappelijke artikelen over graslandgebruik uit de periode van 1958 tot 2019 gecontroleerd op relevantie voor dit onderzoek. Er waren twee reviews beschikbaar die een overzicht geven van de beschikbare literatuur tot moment van publicatie in 1999 en 2009 (Peyraud en González-Rodríguez, 1999; Decruyenaere et al., 2009). Tenslotte zijn alle relevante artikelen na 2009 geselecteerd met als criteria dat ze specifiek gaan over het schatten van de grasopname op melkveebedrijven. Het tussenproduct van deze stap was een notitie van 2 à 3 A-4 die geïntegreerd is in dit rapport.

\subsection{Inventarisatie benaderingen nationale en internationale experts}

$\mathrm{Na}$ het literatuuronderzoek zijn experts op verschillende manieren geraadpleegd. Alle betrokken experts staan benoemd in bijlage 1 . De internationale experts (6) zijn benaderd om inzicht te krijgen in recente ontwikkelingen in het buitenland. In bijlage 2 staat de mail die naar hen is verzonden. De Nederlandse experts zijn geselecteerd op basis van een diversiteit in stakeholders zoals diervoederbedrijven, zuivelbedrijven, adviseurs, accountants en onderzoekers.

De mail die verstuurd is aan de nationale experts (5) staat in bijlage 3. Daarnaast zijn er nationale experts (7) uitgenodigd voor een workshop. Het doel van de workshop was inventariseren. Allereerst hebben we de aanleiding en de achtergrond van het project geschetst en een overzicht van de bevindingen uit de literatuur en de reacties op de mails van internationale en nationale experts gegeven. Vervolgens hebben we een brainstormsessie gehouden waarbij we hebben gevraagd om zoveel mogelijk te denken zonder beperkingen aangaande kosten, borgbaarheid e.d. zodat er geen creatieve benaderingen in het proces verloren gaan door te starten met te nauwe kaders. Vervolgens hebben we alle benaderingen opgedeeld in korte en middellange termijn en nagedacht over criteria waaraan de benaderingen aan zouden moeten voldoen. Het tussenproduct van deze stap was een groslijst met opties op flap en gespreksverslagen die zijn geïntegreerd in dit rapport.

\subsection{Synthese}

$\mathrm{Na}$ de inventarisatiefase is een synthesefase gestart waarbij de verschillende benaderingen die naar voren kwamen uit het literatuuronderzoek en de input van nationale en internationale experts beschreven zijn. De verschillende benaderingen die tijdens de workshop opgesplitst waren in korte en (middel-)lange termijn zijn verder uitgeschreven en gecombineerd met de bevindingen uit literatuur en de reacties van internationale en nationale experts. Het tussenproduct was een uitwerking van de verschillende benaderingen op 2 à 3 A-4 die is geïntegreerd in dit rapport.

Om weging te geven aan de verschillende benaderingen zijn criteria vastgesteld met het projectteam waaraan de benaderingen moeten voldoen om te kunnen worden gebruikt in de KringloopWijzer. 
Vervolgens hebben de auteurs een matrix opgesteld en alle bovengenoemde benaderingen gescoord met een puntentelling van 1-5 en ze vervolgens gerangschikt op totale score. Hierbij is uitgegaan van gelijke weging. Op basis van deze procedure is een shortlist gemaakt van benaderingen. Deze syntheseresultaten zijn besproken in de klankbordgroep rondom de BEP-pilot en in de stuurgroep "Wetenschappelijke doorontwikkeling KringloopWijzer" (bijlage 1) om de benaderingen en criteria te toetsen.

\subsection{Uitwerking suggestie korte termijn}

Als laatste stap is de meest perspectiefvolle korte termijn benadering voor grasopname en voor de $\mathrm{N}$ en P-gehalten uitgewerkt in een korte notitie. Deze notitie is besproken in de stuurgroep

'Wetenschappelijke Doorontwikkeling KringloopWijzer' en de notitie is vervolgens geïntegreerd in deze rapportage, waarbij de inhoudelijke aanvullingen van de stuurgroep zijn meegenomen. 


\section{$3 \quad$ Literatuuroverzicht}

\subsection{Grasopname in de kringloopwijzer}

Momenteel berekent de KringloopWijzer de opname van vers gras met formule 1, waarbij de koeien de eerste twee uur $1 \mathrm{~kg}$ ds vers gras (per uur) opnemen en de overige uren 0,75 kg ds vers gras (Schröder et al., 2019). Verder wordt standaard gerekend met $960 \mathrm{VEM} / \mathrm{kg}$ ds.

Grasopname kg ds per dag $=2+0,75 \times$ (weide-uren/dag - 2); weide-uren/dag $\leq 20$

[formule 1]

Vervolgens wordt op basis van de melkproductie en de leeftijd van de koe de totale VEM-behoefte berekend. Daarnaast wordt ook met behulp van de aangelegde kuilen en formule 1 de totale opname berekend. Deze twee berekeningen worden vergeleken en daarbij wordt de berekende opname bijgesteld (naar beneden of naar boven) in de berekende verhouding met de verbruikte (gemeten voorraden) hoeveelheid graskuil en maiskuil. Dit is schematisch weergegeven in Figuur 1.

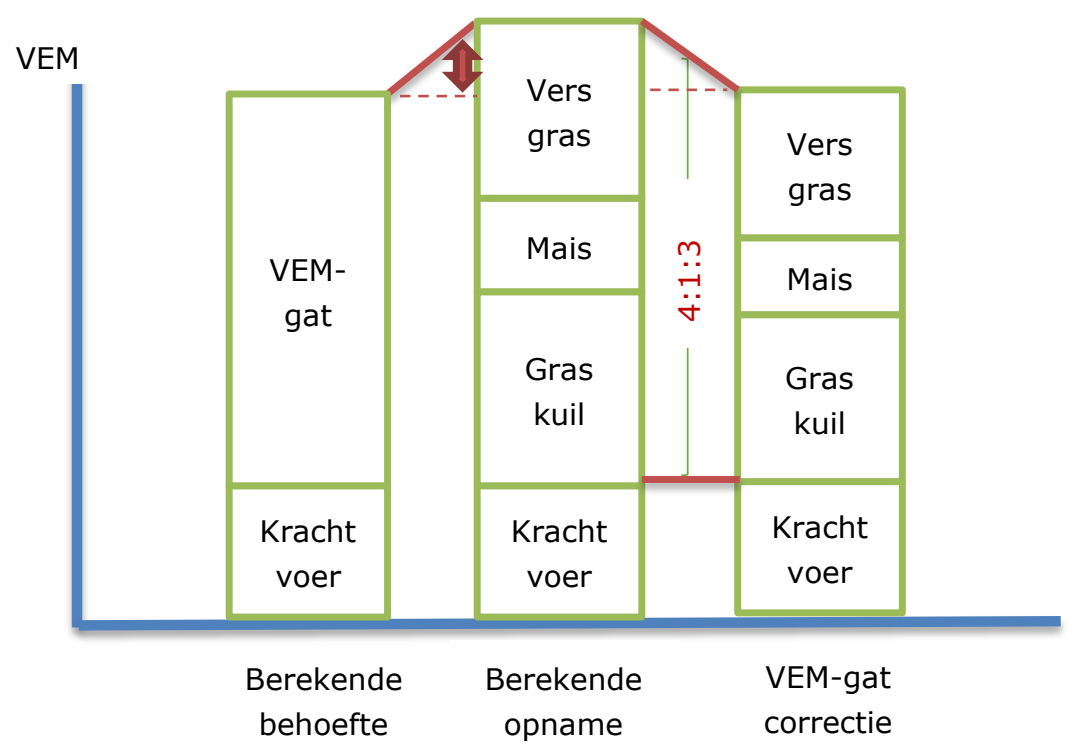

Figuur 1 Schematische weergave van de berekening van grasopname op basis van de berekende verhouding met de verbruikte (gemeten voorraden) hoeveelheid graskuil en maiskuil.

De gehalten van $\mathrm{N}$ en $\mathrm{P}$ in het vers gras zijn afhankelijk gesteld van aangelegde graskuilen in de verhoudingen volgens formule 2 en 3.

N/VEM vers gras $=1.12 \times$ N/VEM ingekuild gras

[formule 2]

$\mathrm{P} / \mathrm{VEM}$ vers gras $=0.97 \times \mathrm{P} / \mathrm{VEM}$ ingekuild gras

[formule 3]

Er zijn een aantal rapporten verschenen waarin de resultaten van de KringloopWijzer zijn geanalyseerd op gevoeligheid en onzekerheid voor specifieke doelgroepen of spreiding rondom invoergegevens. Šebek et al. (2018) beschrijven een analyse naar de invloed van moeilijk controleerbare invoergegevens, met een specifieke focus op extensieve weidegang melkveebedrijven. Šebek et al. (2018) geven aan dat de samenstelling van vers gras invloed heeft op de resultaten van de KringloopWijzer, maar dat de vers grasopname zelf geen grote invloed heeft. Holster et al. (2015) hebben een quick scan uitgevoerd waarbij gekeken is naar het effect van een foutieve invoer voor de belangrijkste invoerparameters en de relevantie hiervan voor de uitkomsten van de KringloopWijzer. Ze beschrijven dat er enkel sprake is van gevoeligheid bij grote verschillen in weidegang, maar dat de relevantie hiervan voor de praktijk beperkt is. 
Oenema et al. (2017a) toetsten de KringloopWijzer aan de hand van meerjarige metingen op Koeien \& Kansen bedrijven en concluderen dat met name de geschatte gehalten in het vers gras afwijken van de metingen. In dit rapport staat ook dat de mate waarin de voorspellingen van excretie en gewasopbrengst via de KringloopWijzer afwijken van metingen op individuele Koeien \& Kansen bedrijven geen verband houdt met de beweiding in het traject van 0-30\% vers grasopname. Oenema et al. (2017b) hebben een algemene onzekerheids- en gevoeligheidsanalyse uitgevoerd en vonden net als Šebek et al. (2018) dat uren weidegang en de rekenregel voor het bepalen van de hoeveelheid vers grasopname in het rantsoen weinig tot geen invloed hebben op de onzekerheid van de berekende excreties en gewasopbrengsten. Een uitzondering hierop zijn bedrijven met veel weidegang ( $>4.200$ uur per jaar). Oenema et al. (2017b) verklaren dit door onzekerheid met betrekking tot gehalten in vers gras. Op basis van deze rapporten concluderen wij dat de gevoeligheid van grasopname niet erg groot is voor $\mathrm{N}$ - en $\mathrm{P}$ excretie en dat graskwaliteit een grotere invloed heeft dan de grasopname op $\mathrm{N}$ en $\mathrm{P}$ excretie. Met name bedrijven met veel weidegang wijken af qua grasopname en kwaliteit. Een belangrijk knelpunt hierbij is dat de variatie in vers grasopname en kwaliteit gedurende het seizoen niet zijn meegenomen. In het algemeen loopt de KringloopWijzer uit de pas bij veel weidegang en droogte. Ondanks dat bovenstaande rapporten laten zien dat uren weidegang en de rekenregel voor het bepalen van de hoeveelheid vers grasopname in het rantsoen weinig tot geen invloed hebben op de onzekerheid van de berekende excreties en gewasopbrengsten leidt de huidige werkwijze tot discussie in de praktijk. Dit laat zien dat de perceptie van de melkveehouder over de juistheid van de uitkomsten ook heel belangrijk is. En daarnaast zijn deze gevoeligheidsanalyses gedaan voor $\mathrm{N}$ - en $\mathrm{P}$ excretie, maar ook andere duurzaamheidsindicatoren krijgen een steeds grotere rol. Een voorbeeld hiervan is het effect van aantal uren weidegang en de bijbehorende hoeveelheid vers grasopname op de ammoniakemissie.

\subsection{Factoren van invloed op grasopname}

Het literatuurreview van Decruyenaere et al. (2009) geeft een overzicht van factoren die grasopname beïnvloeden (figuur 2). Een belangrijke boodschap uit figuur 2 is dat de uiteindelijke grasopname niet alleen wordt beïnvloed door de duur van de beweiding, maar ook door de snelheid waarmee het gras wordt opgenomen. Dit wordt vaak beschreven in de literatuur door hapfrequentie vermenigvuldigd met hapgrootte vermenigvuldigd met graastijd (Hellwing et al., 2015). Een andere belangrijke boodschap uit het literatuurreview is dat het niet mogelijk is om met uitsluitend beweidingstijd een precieze berekening van grasopname te maken. Grasopname is multifactorieel, wat wil zeggen dat de grasopname wordt bepaald door meerdere factoren tegelijk. De factoren zijn gerelateerd aan voereigenschappen, koe-eigenschappen, beweidingsmanagement, koegedrag en omgeving. Al deze factoren beïnvloeden de motivatie van de koeien om te grazen door beperkingen in graasgedrag op korte en middellange termijn.

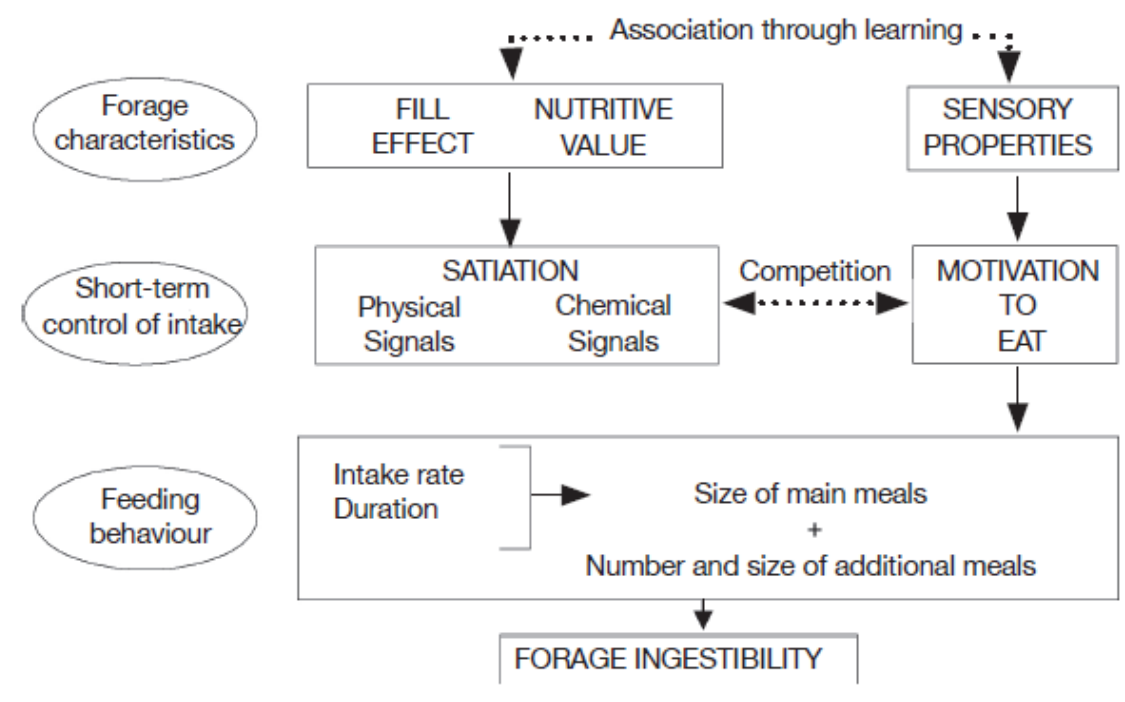

Figuur 2 Overzicht van factoren die de grasopname beïnvloeden (Baumont et al., 2000). 
In het literatuurreview van Peyraud en González-Rodríguez (1999) staat dat aanbod van vers gras een van de primaire factoren is die grasopname beïnvloedt. Meerdere studies hebben een sterke kromlijnige relatie gevonden tussen grasopname en aanbod van vers gras. In figuur 3 uit Delagarde et al. (2001) is de relatie te zien tussen grasopname en aanbod van vers gras (zwarte punten) en tussen aanbod van vers gras en graslandbenutting (witte punten). Kortom: hoe meer aanbod, hoe meer opname, hoe lager de benutting.

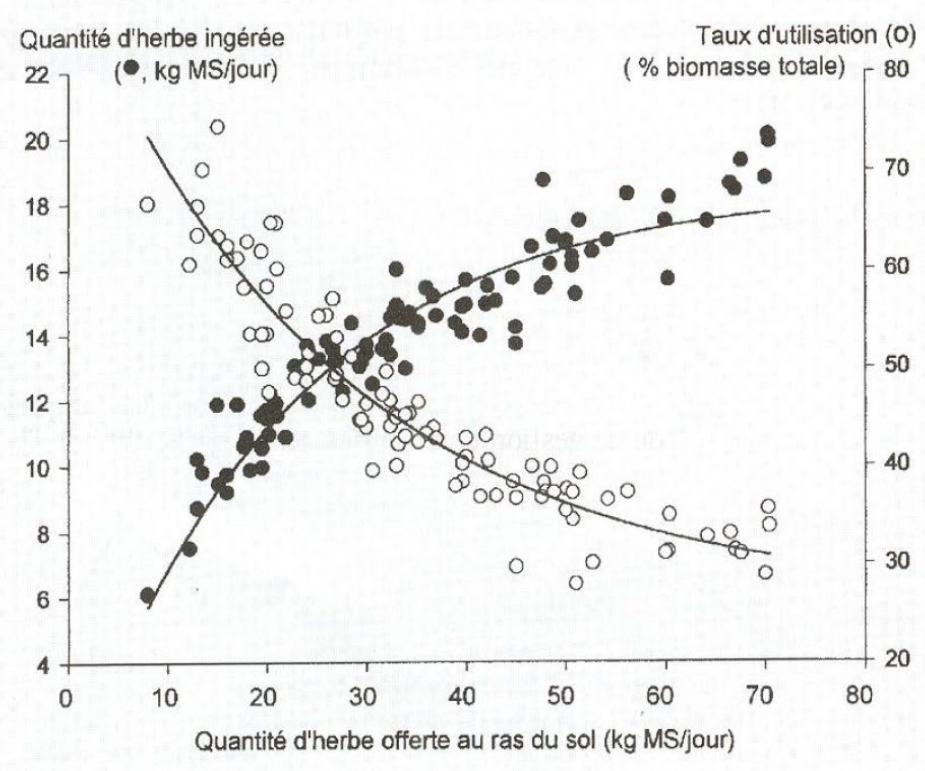

Figuur 3 De relatie tussen grasopname, aanbod van vers gras en grasland benutting (Delagarde et al. (2001)

Met name Delagarde et al. (2011) heeft uitgebreid gekeken naar de relatie tussen beweidingstijd en opname. Figuur 4 toont de grasopname bij verschillende niveaus van aanbod van vers gras; het bovenste plaatje bij roterend weiden en het onderste bij standweiden. Opvallend aan deze plaatjes is dat de opnames allemaal afvlakken, met een grotere helling in de eerste uren beweiding. Nu zit dit deels in de formule van de KringloopWijzer aangezien bij beweiding wordt gestart met $2 \mathrm{~kg}$ opname in de eerste twee uur en dan ieder uur $0,75 \mathrm{~kg}$ ds. De lineaire toename van 2 tot 18 uur is echter niet in lijn met de literatuur. 

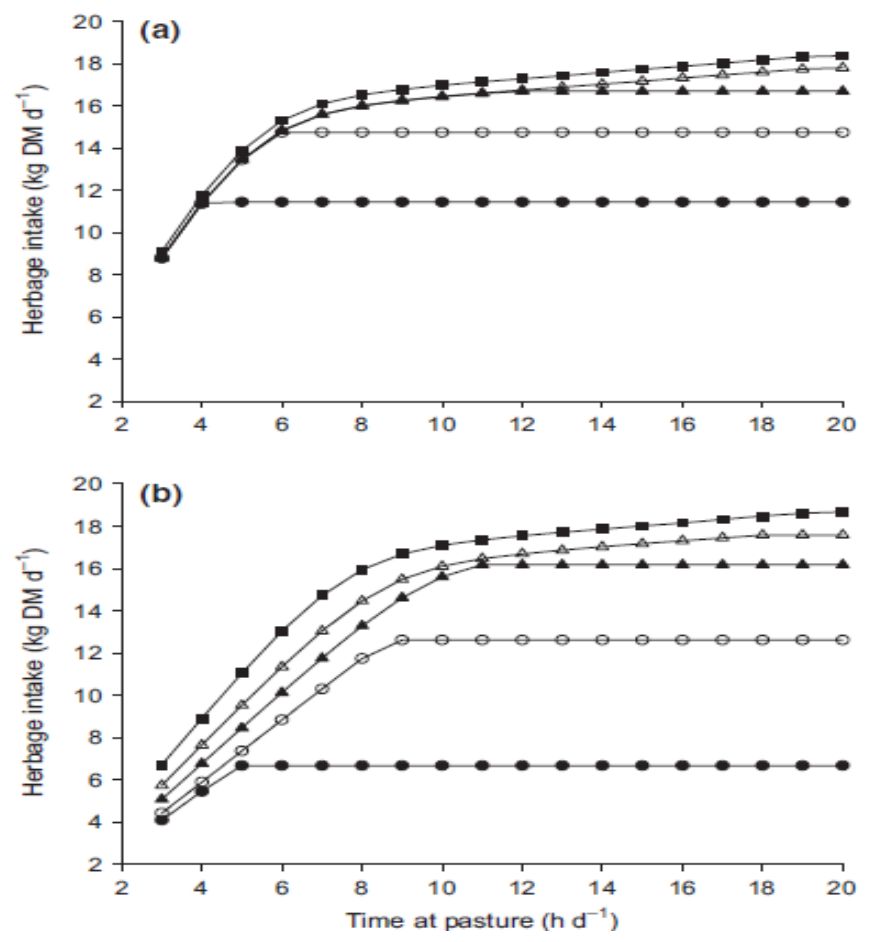

Figuur 4 Gesimuleerde effecten van beweidingstijd op opname van melkkoeien met a) roterend weiden met toenemend aanbod van vers gras van 8, 12, 16, 20 en $24 \mathrm{~kg}$ ds per dag (boven de $5 \mathrm{~cm}$ ) en b) standweiden met toenemende grashoogtes van 3, 4, 6, 8 en 10 cm, uit: Delagarde et al. (2011).

Op basis van literatuur zijn we tot de conclusie gekomen dat de grasopname kan worden bepaald met de volgende formule:

Grasopname $(\mathrm{kg}$ ds per dag $)=$ graastijd $($ minuten per dag $) *$ hapfrequentie $($ happen per minuut $) *$ hapgrootte (kg ds per hap); waarbij: hapfrequentie $*$ hapgrootte $=$ opnamesnelheid

De graastijd kan worden afgeleid op basis van de toegangstijd tot de weide door middel van formule 4, een relatie beschreven door Chilibroste et al. (2015) op basis van 12 beweidingsstudies:

Toegang tot de weide $(\%)=0,9269^{\mathrm{e}-0,037^{*} \text { toegangstijd, } \text { met toegangstijd in uren per dag [Formule 4] }}$

In Nederlandse weidesystemen met onbeperkt weiden en lage bijvoeding is de hapfrequentie ongeveer 60 happen per minuut en de hapgrootte ongeveer $0,5 \mathrm{~g}$ ds per hap, wat resulteert in een opnamesnelheid van 30 gram per minuut (Abrahamse, 2009). Slechts enkele studies tonen het effect van een hoge bijvoeding inclusief ruwvoer op graasgedrag. Zo laten Pérez-Prieto et al. (2011) zien dat een hoge bijvoeding van ruwvoer in combinatie met een laag aanbod van vers gras kan zorgen voor een afname in opnamesnelheid tot 17 gram ds per minuut.

\subsection{Methodieken om grasopname te meten}

Er zijn verschillende methodieken om grasopname te meten beschikbaar, zowel directe als indirecte metingen. Decruyenaere et al. (2009) beschrijven twee directe metingen:

- De klassieke methode is het meten van de biomassa voor en na beweiding. Dit kan met behulp van een grashoogtemeter of door het uitmaaien van strookjes gras. Deze methode is met name betrouwbaar bij roterende systemen (omweiden) en is geschikt om de grasopname op kuddeniveau te schatten. 
- De tweede methode is verandering in lichaamsgewicht, maar de betrouwbaarheid hiervan hangt sterk af van de precisie van de weegunit en gewichtsverlies door mesten/urineren tijdens de meetperiode.

Daarnaast zijn er meerdere indirecte metingen beschikbaar:

- De n-alkanen methode is de 'gouden standaard' voor onderzoeksdoeleinden (Dove en Mayes, 1996). De methode is gebaseerd op gebruik van een marker in het voer dat vervolgens wordt getraceerd in de mest. Op basis van de verhouding van de marker en natuurlijk voorkomende C-ketens in het voer en in de mest kan de vers grasopname worden berekend. Bij deze methode is de uitdaging om representatieve monsters te nemen van het opgenomen gras.

- Meerdere studies beschrijven het automatisch registreren van graasactiviteit zoals herkauwen en opnametijd met sensoren. Deze methode is veelvuldig getest en geschikt om graastijd en opnamesnelheid te bepalen (Oudshoorn et al., 2013; Andriamandroso et al., 2016).

- $\quad$ Een opkomende methodiek is het bepalen van grasopname door een NIRS analyse uit te voeren op melk- of mestmonsters (Decruyenaere et al., 2012). De grootste uitdaging bij deze methodiek is het ontwikkelen van een grote kalibratiedataset die representatief is voor een verscheidenheid aan praktijksituaties.

Naast deze meetmethodieken is er ook nog een verscheidenheid aan empirische modellen die op basis van dierprestatie en opnamecapaciteit de grasopname kunnen schatten. Veel van deze modellen rekenen in de basis vanuit opnamecapaciteit en/of energiebehoefte en zetten daar voereigenschappen naast. In meer en mindere mate vullen ze de modellen aan met parameters gelinkt aan koegedrag en beweidingsmanagement. Per model verschilt het dus ook hoeveel data nodig is van melkveehouders. Een model dat toepasbaar is voor de Nederlandse situatie is het model 'Grazevision' van Zom en Holshof (2011) waarbij bijvoorbeeld toegangstijd tot de wei, beweidingsoppervlak en selectie door koeien zijn meegenomen aangaande beweidingsmanagement en koegedrag. In meerdere studies wordt genoemd dat de fout gerelateerd aan het schatten van grasopname met empirische modellen ongeveer 10 tot $20 \%$ is en dat dit ongeveer overeenkomt met 1 tot $2 \mathrm{~kg}$ per koe per dag (RocaFernández en González-Rodríguez, 2017; Rombach et al., 2019). Roca-Fernández en GonzálezRodríguez (2017) beschrijven dat modellen met een fout kleiner dan 10\% eigenlijk gewenst zijn, maar dat modellen met een fout van 10-20\% als relatief goed en acceptabel worden gezien.

\subsection{Conclusies op basis van de literatuur}

- Als je opname van vers gras goed wilt inschatten heb je meer inzicht nodig dan alleen beweidingsuren;

- Een modelmatige benadering op basis van opnamecapaciteit en/of voederbehoefte en bijvoeding biedt perspectief voor het schatten van vers grasopname; eventueel aangevuld met gegevens aangaande beweidingsmanagement (beweidingsoppervlak, moment van beweiding op de dag en/of in het seizoen);

- Een modelmatige benadering van vers grasopname wordt gecombineerd met een grasgroeimodule voor graskwaliteit in het Nederlandse model 'Grazevision' van Zom and Holshof (2011);

- Op de lange termijn bieden sensoren of aanvullende analyses in vers gras/melkmonsters perspectief voor grasopname en graskwaliteit, maar hier is aanvullende validatie voor nodig. 


\section{$4 \quad$ Inventarisatie benaderingen experts}

\subsection{Mailconsultatie}

De huidige methode van bepalen van de vers grasopname, met bijbehorende gehalten, in de KringloopWijzer is zowel door internationale experts als door nationale experts beoordeeld. De internationale experts gaven aan dat het een grote uitdaging is om voor de praktijk haalbare metingen uit te voeren met voldoende nauwkeurigheid. Het ligt in de lijn der verwachting dat er afwijkende resultaten optreden bij een berekeningssysteem dat voor alle melkveebedrijven wordt gebruikt en waarbij beweiding een rol speelt. Het gebruik van het systeem steunt dan ook op een balans tussen precisie en haalbaarheid: hoe precies moet het zijn en wat is haalbaar in de praktijk?

De internationale experts beschreven een aantal situaties die mogelijk kunnen zorgen voor afwijking van de daadwerkelijke grasopname en bijbehorende gehalten:

- Koeien die na het melken gevoerd worden en dan naar buiten gaan, gaan direct liggen wat waarschijnlijk zorgt voor een lagere grasopname in de eerste 2 uur;

- Bij veel beweiding/weinig bijvoeding kunnen koeien meer opnemen per uur, met name in het eerste uur van beweiding;

- De huidige methode werkt waarschijnlijk wel redelijk bij inscharen en bij uniforme weidesnedes Engels raaigras, maar niet bij afwijkende grasbestanden en bijzondere beweidingssystemen zoals Kurzrasen; zowel de grasopname als de graskwaliteit kunnen dan afwijken.

Daarnaast beschreven de internationale experts de volgende opties voor verbetering van het schatten van de grasopname en bijbehorende gehalten:

- Meten van de grasvoorraad vóór en na inscharen, waarbij inzicht wordt verkregen in de grasopname op koppelniveau;

- $\quad$ Bemonsteren van de bodemvoorraad op N en P waardoor inzicht wordt verkregen in de graskwaliteit;

- $\quad$ Onderscheid maken tussen verschillende systemen: gebruik een tabel met vaste waarden voor combinaties van beweidingssystemen, intensiteiten en beweidingsduren;

- $\quad$ Modelberekeningen op basis van energiebehoefte koeien en voerkwaliteit; inzet van regressie. coëfficiënten voor gewicht koe, melkproductie, kwaliteit ruwvoer;

- Modelberekeningen op dagbasis: behoefte minus opname overige voedermiddelen, verschil is berekende grasopname;

- Gebruik graslandkalender in combinatie met voerkalender; belangrijke beweidingsperioden meenemen; in overleg met adviseur - ongeveer 1 uur per keer nodig voor discussie en juiste invoer.

De nationale experts gaven de volgende opties voor verbetering van het schatten van de opname van vers gras en de bijbehorende gehalten:

Korte termijn

- Koppelen urenregistratie weidegang zuivelbedrijven met KringloopWijzer (MelkWeb, Z-net);

- Periode en uren weidegang koppelen aan graskwaliteit;

- Uren registreren per maand en N/P linken aan graskuil in de betreffende maand i.p.v. jaargemiddelde;

- De graslandproductie (kg vers gras) gebruiken als uitgangspunt voor berekeningen en borging in plaats van het aantal uren weidegang;

- N/P gehalten koppelen aan regionale analyses en periode van weidegang in het jaar;

- Subgroepen maken voor grasopname en kwaliteit (regio/grondsoort/intensiteit); 
- $\quad$ Rekenen vanuit energiebehoefte en bijvoeding.

Lange termijn

- Directe graslandmetingen biomassa/kwaliteit i.p.v. afgeleide metingen;

- Landelijk dekkend meetnetwerk kalibreren (bijvoorbeeld via AkkerWeb of grasgroeimeetnet);

- Sensoren voor opname per hap en graslengte of biomassa, daarnaast mogelijk ook voor bodemmetingen in relatie tot grasgroei.

Veel bevindingen uit de literatuur komen overeen met de benaderingen van de internationale en nationale experts, met name de bevindingen dat grasopname sterk afhankelijk is van de opnamesnelheid en dat deze snelheid in de praktijk nog wel eens kan verschillen afhankelijk van tijdstip van de dag bijvoorbeeld. Een andere overeenkomst is dat extra gegevens rondom graslandmanagement kunnen bijdragen aan een modelmatige benadering en dat metingen met behulp van sensoren nog vraagt om verdere validatie. Daarbij is ook nadrukkelijk de opmerking gemaakt dat relevantie rondom gegevens grasopname en grazen op basis van directe metingen de komende jaren toe zal nemen n.a.v. (aangescherpte) normen voor grondgebondenheid en rondom ammoniakemissie.

\subsection{Workshop}

De bevindingen uit het literatuurreview en de reacties per mail door nationale en internationale experts zijn tijdens de workshop met nationale experts gedeeld ter introductie van de brainstormsessie. In een eerste ronde zijn mogelijke benaderingen geïnventariseerd met behulp van het opschrijven op geeltjes. Op basis van deze geeltjes is vervolgens tijdens de workshop een indeling gemaakt in vier denklijnen. Figuur 5 toont een overzicht van alle benaderingen die naar voren zijn gekomen tijdens de workshop verdeeld in deze vier denklijnen die Kwadrant A-D zijn genoemd.

Kwadrant A: een denklijn op basis van het aanpassen van parameters in de huidige formules met huidige invoer. Kwadrant B: een denklijn op basis van het aanpassen van de formules zonder (B1) of met (B2) extra invoer. Kwadrant A en kwadrant B zijn benaderingen voor de korte termijn. Kwadrant C: een denklijn met additionele metingen op bedrijfsniveau. Kwadrant D: een denklijn met additionele metingen op een globaler niveau. Deze twee kwadranten zijn benaderingen voor de langere termijn. In het volgende overzicht zijn de benaderingen in deze vier kwadranten verder uitgewerkt. Hierbij wel de opmerking dat de nadruk bij verdere uitwerking van benaderingen ligt op de kortere termijn en dat de benaderingen in de kwadranten A en B daarom concreter beschreven zijn dan de benaderingen in kwadranten $C$ en $D$.

Kwadrant A: Benaderingen voor aanpassing van parameters in de huidige formules voor grasopname en kwaliteit. Dit kan door de relatie tussen uren en grasopname of de relatie tussen N- en P-gehalten in graskuil en vers gras te updaten (bijvoorbeeld via Amazing Grazing (www.amazinggrazing.eu), of vanuit kennis bij WUR). In dit kwadrant blijft de aanpassing beperkt tot de parameters in de formule. Verder blijven de formule en parameters gelijk voor alle type melkveebedrijven.

Kwadrant B1: Benaderingen voor aanpassing van de huidige formules voor grasopname en kwaliteit waarbij de parameters kunnen variëren voor verschillende type melkveebedrijven en waarbij de opzet van de formule ook aangepast kan worden. In dit kwadrant blijft de huidige invoer gelijk en zal alleen de formule aangepast worden. Bijvoorbeeld door:

- $\quad$ Groepen maken op basis van melksysteem (robot of traditioneel). Op basis van expertkennis zou bijvoorbeeld een uitspraak gedaan kunnen worden over verschil in grasopname afhankelijk van melksysteem; dit is echter momenteel nog niet te onderbouwen met wetenschappelijke literatuur.

- $\quad$ Groepen maken op basis van intensiteit op bedrijfsniveau en deze koppelen aan een inschatting van de bijvoeding. De veronderstelling is dat het bijvoedingsniveau op intensieve bedrijven hoger is dan op extensieve bedrijven. Maar hier is ook weer een afhankelijkheid van de grootte van de huiskavel. Doordat de grootte van de huiskavel niet bekend is blijft het onzeker hoeveel er daadwerkelijk geweid is en wat het bijvoedingsniveau zal zijn. 
- $\quad$ Geen onderscheid maken tussen opname van kuilgras en vers gras. Dit zou betekenen dat de totale hoeveelheid gras sluitpost wordt en de uren weidegang niet meer gebruikt worden voor het schatten van de vers grasopname ten behoeve van de $\mathrm{N}$ - en P-excretie. Een berekening zonder weidegang is echter onwenselijk, omdat ammoniak- en lachgasemissies ook afhankelijk zijn van de mate van weidegang.

- $\quad$ De methode om het VEM-gat te vullen herzien, waarbij er mogelijk niet evenredig wordt gecorrigeerd tussen de verschillende voercomponenten. Dit zou verkend kunnen worden, maar een risico hier is dat er negatieve of onrealistisch hoge grasopnames kunnen ontstaan.

Kwadrant B2: Aanpassen formule op basis van (beperkte) extra invoer:

- $\quad$ Aansluiten op de weidekalender, en dan met name wanneer de dieren in het jaar naar buiten gaan. Hiermee kun je per seizoen de opname en de gehalten aanpassen:

- Eventueel in combinatie met grondsoort, want op veengrond is het gehalte van $\mathrm{N}$ in vers gras hoger in het najaar dan bij andere grondsoorten;

- Eventueel in combinatie met stikstofleverend vermogen van de bodem (NLV) en/of botanische samenstelling voor beter inschatten van gehalten.

- $\quad$ Opvragen van de huiskavelgrootte waardoor we op basis van literatuur en expertkennis beter in kunnen schatten welke grasopname we verwachten;

- $\quad$ Opvragen van de totale grasopbrengst. Op basis van deze invoer zou de vers grasopname bepaald kunnen worden door de totale grasopbrengst te verminderen met de graskuil;

- $\quad$ Inzicht krijgen in de hoeveelheid bijvoeding voor de weideperiode om vervolgens groepen te maken met bijvoedingsniveau en zo in te schatten op basis van literatuur en expertkennis welke grasopname we verwachten:

- Opvragen van de voorraadwijzigingen van ruwvoer en krachtvoer om zo de voeropname in de stalperiode en de weideperiode te kunnen onderscheiden;

- Opvragen van het bijvoedingsniveau voor het hele weideseizoen;

- Opvragen van het bijvoedingsniveau per maand: koppelen met weidekalender.

- $\quad$ Opvragen van het beweidingssysteem. Definitie van beweidingssysteem zou door experts moeten worden ingevuld: een kanttekening is echter dat er veel tussenvormen zijn;

- $\quad$ Opvragen van het ras en op basis van literatuur en expertkennis onderscheid maken op basis van graasgedrag (agressiviteit van grazen) in snelheid van grasopname.

Kwadrant C: Additionele metingen op bedrijfsniveau

- Gebruik van (nieuwe) meettechnieken:

- Sensoren in de grasmat voor grasgroei (grasopname) en graskwaliteit.

- Sensoren voor graasactiviteit voor bepalen grasopname.

- Satellietbeelden voor schatten van biomassa en daaruit groei/opbrengst.

- Weidepoorten voor het registreren van beweidingsuren.

- Weegunit voor gewicht koeien voor en na weidegang.

- Weegunit voor graskuil en maiskuil of nauwkeuriger opmeten (voor/tijdens de zomerperiode).

- $\quad$ Aanvullende monstername of analyse:

- Melkmonsters aanvullend analyseren voor bepalen vers grasopname of mogelijk ook op basis van ureum in combinatie met bijvoeding.

- Grasmonsters voor N- en P- gehalten: wekelijks of maandelijks vers grasmonster of op basis van kuilmonster gerelateerd aan de weideperiode.

- Opvragen van de botanische samenstelling van het vers gras (morfologisch) om zo een betere inschatting te kunnen maken van de $\mathrm{N}$ - en $\mathrm{P}$ - gehalten.

- Invoeren van een keuzeoptie in de KringloopWijzer waarbij gekozen kan worden voor bedrijfsspecifieke rekenregels op basis van additionele metingen.

Kwadrant D: Additionele metingen op een globaler niveau

- Parameters en/of formules verbeteren (actueel, dus tijdens seizoen) met behulp van een validatie netwerk:

- Satellietbedrijven per regio waar de graskwaliteit ( $\mathrm{N}$ - en P-gehalten) wordt gemeten.

- Sensoren en/of monstername op pilotbedrijven voor grasopname en kwaliteit. 
- Referentieregio's voor gehalten.

- Koppelen met meetnet voor vers grasopname en kwaliteit.

- $\quad$ Een grasgroei model nemen als basis voor de berekeningen in de KringloopWijzer in plaats van het Koemodel, en dan met name voor N- en P-gehalten.

- $\quad$ Suikergehalte als indicator voor smaak en vers grasopname.

- Gehalten in het vers gras met terugwerkende kracht bepalen op basis van historische data, bijvoorbeeld van het afgelopen seizoen of van de afgelopen drie seizoenen. 


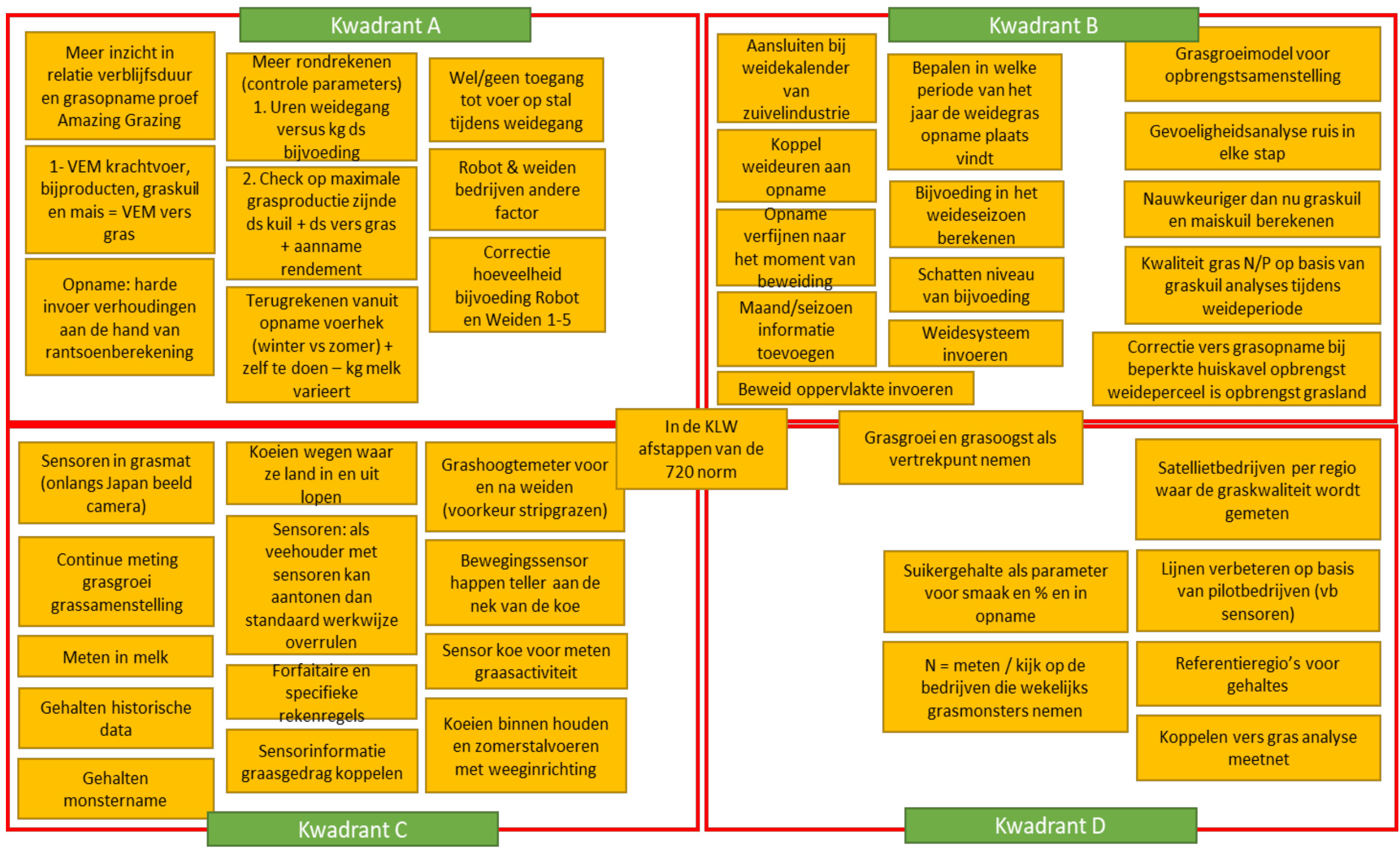

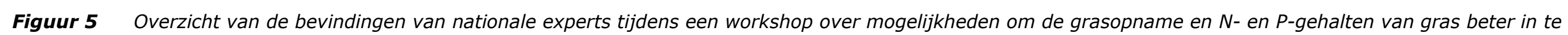
schatten in de KringloopWijzer. 


\section{$5 \quad$ Synthese op basis van literatuur en kennis van experts}

Met name in de brainstorm tijdens de workshop met nationale experts hebben we gevraagd om zoveel mogelijk te denken zonder beperkingen aangaande lasten (o.a.adminstratieve), borgbaarheid en dergelijke. Gezien de context hebben we hier echter wel mee te maken en hebben we in de synthese criteria opgesteld waar de benaderingen aan moeten voldoen om bruikbaar te zijn in de KringloopWijzer. Allereerst hebben we aan het einde van de workshop gevraagd naar criteria waar de benadering aan moet voldoen om ook toegepast te kunnen worden in de praktijk. Op basis van deze input hebben de auteurs de criteria geclusterd en de onderstaande shortlist met zeven criteria opgesteld om de geopperde benaderingen te wegen.

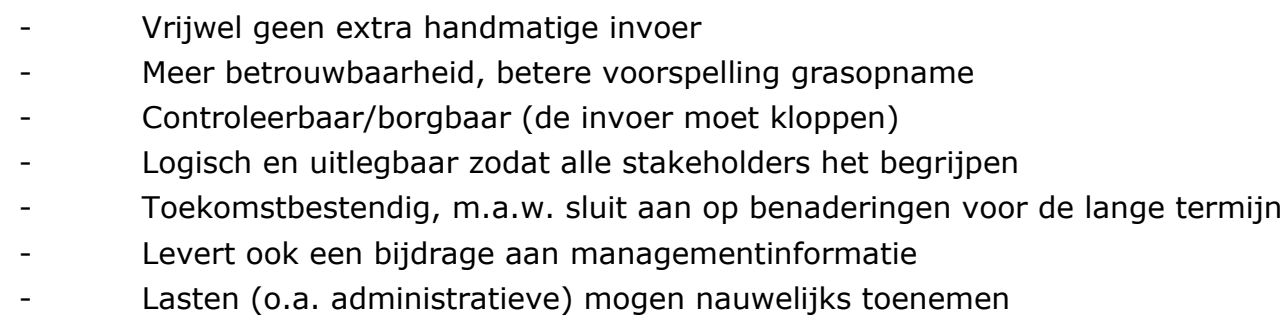

Deze criteria zijn gebruikt om een selectie te maken van de bevindingen uit de literatuur en alle benaderingen van internationale en nationale experts. Op basis van een matrix hebben de auteurs van dit rapport alle eerder beschreven benaderingen gescoord met een puntentelling van 1-5 en ze vervolgens gerankt op totale score. Hierbij is uitgegaan van gelijke weging. Op basis van de ranking kwamen de volgende benaderingen naar voren als perspectiefvolle opties voor de korte termijn:

Kwadrant A: Verbeter rekenregels zonder extra invoer

- $\quad$ De relatie tussen uren weidegang en grasopname verbeteren (Amazing Grazing).

Kwadrant B2: Verbeter rekenregels met extra invoer

- $\quad$ Opvragen wanneer de koeien naar buiten gaan (koppelen met zuivelbedrijven; weidegangkalender).

- $\quad$ Opvragen van de hoeveelheid bijvoeding door middel van voorraadwijzigingen in ruwvoer en krachtvoer om zo de voeropname in de stalperiode en de weideperiode te kunnen scheiden.

- Opvragen van de huiskavelgrootte waardoor we op basis van literatuur en expertkennis beter in kunnen schatten welke grasopname we verwachten. De grootte van de huiskavel is beter objectief vast te stellen dan de hoeveelheid bijvoeding.

De formules aanpassen op basis van huidige invoer (kwadrant B1) bleek onvoldoende betrouwbaar en is daarmee uit de selectie gevallen. Voor kwadrant $C$ is het noodzakelijk dat er eerst verdere ontwikkelingen in techniek plaatsvinden en voor kwadrant $D$ is het van belang dat er eerst verkennende analyses worden uitgevoerd. Deze bevindingen zijn gedeeld met de klankbordgroep en de stuurgroep 'Wetenschappelijke Doorontwikkeling KringloopWijzer'. Het advies was om te focussen op het verbeteren van de relatie uren weidegang en opname van vers gras (kwadrant A). Verbeteren van de rekenregels zonder extra invoer heeft sterk de voorkeur. De grootte van de huiskavel als extra input-parameter werd echter ook zinvol gevonden, maar dan vooral ter controle en signalering. In verband met eisen aan de hoeveelheid 'eiwit van eigen land' op het melkveebedrijf is de grootte van de huiskavel voor meerdere doelen te gebruiken. Daarnaast is de grootte van de huiskavel beter objectief vast te stellen dan de hoeveelheid bijvoeding, en daarmee als basis voor grasopname te gebruiken. Uit dit onderzoek zijn geen concrete benaderingen voor het verbeteren van het schatten van de graskwaliteit naar voren gekomen voor de korte termijn. Uit het literatuuronderzoek bleek echter dat de graskwaliteit de grootste invloed heeft op de $\mathrm{N}$ en $\mathrm{P}$ excretie. 
De stuurgroep 'Wetenschappelijke Doorontwikkeling KringloopWijzer' heeft nadrukkelijk gevraagd om nog een keer te kijken naar mogelijkheden om de $\mathrm{N}$ - en P-gehalten in vers gras beter te schatten. 


\section{$6 \quad$ Uitwerking meest relevante suggesties voor de korte termijn}

\subsection{Grasopname}

Op basis van recent onderzoek van Amazing Grazing is gekeken of de relatie tussen het aantal uren weidegang en de grasopname geactualiseerd kan worden. In dit onderzoek is gevonden dat de werkelijke vreettijd (tijd die de koeien daadwerkelijk besteden aan gras vreten) bij 7 uur overdag weiden ongeveer $80 \%$ van de totale weidetijd (tijd die koeien in de weide doorbrengen) is en de werkelijke vreettijd bij 12 uur's nachts weiden ongeveer $60 \%$ van de weidetijd is. Dit resulteerde in een grasopname van ongeveer $5,5 \mathrm{~kg}$ ds bij 7 uur overdag weiden $(0,8 \mathrm{~kg}$ ds per uur weidetijd) en 6,4 $\mathrm{kg}$ ds bij 12 uur 's nachts weiden $(0,5 \mathrm{~kg}$ ds per uur weidetijd). Als je dit uitdrukt per uur daadwerkelijke vreettijd is dit ongeveer $1 \mathrm{~kg}$ ds bij 7 uur overdag weiden en $0,9 \mathrm{~kg}$ ds bij 12 uur 's nachts weiden. Hierbij zijn geen consistente verschillen gevonden tussen de beweidingssystemen roterend standweiden en stripgrazen. Wat deze resultaten met name laten zien is dat de daadwerkelijke vreettijd erg belangrijk is voor de daadwerkelijke opname. Dit komt overeen met de bevindingen uit het literatuuronderzoek van Chilibroste et al. (2015), die met formule 4 laten zien dat de relatie tussen de weidetijd en de daadwerkelijke vreettijd kan worden beschreven met een negatieve exponentiele functie. De daadwerkelijke vreettijd is in de praktijk echter (nog) niet bekend. Daarnaast wordt de opnamesnelheid bepaald door het aanbod van vers gras en de bijbehorende hoeveelheid bijvoeding. In de literatuur hebben we een range in opnamesnelheid gevonden van zo'n 17 gram ds per minuut bij beperkt weiden en een hoge bijvoeding (Pérez-Prieto et al., 2011) tot 30 gram ds per minuut (60 happen per minuut en 0,5 gram ds per hap) bij onbeperkt weiden en een lage bijvoeding (Abrahamse, 2009). Figuur 6 is opgesteld op basis van deze range in opnamesnelheid en laat een range in grasopname zien in relatie tot de toegangstijd tot de wei en het bijvoedingsniveau.

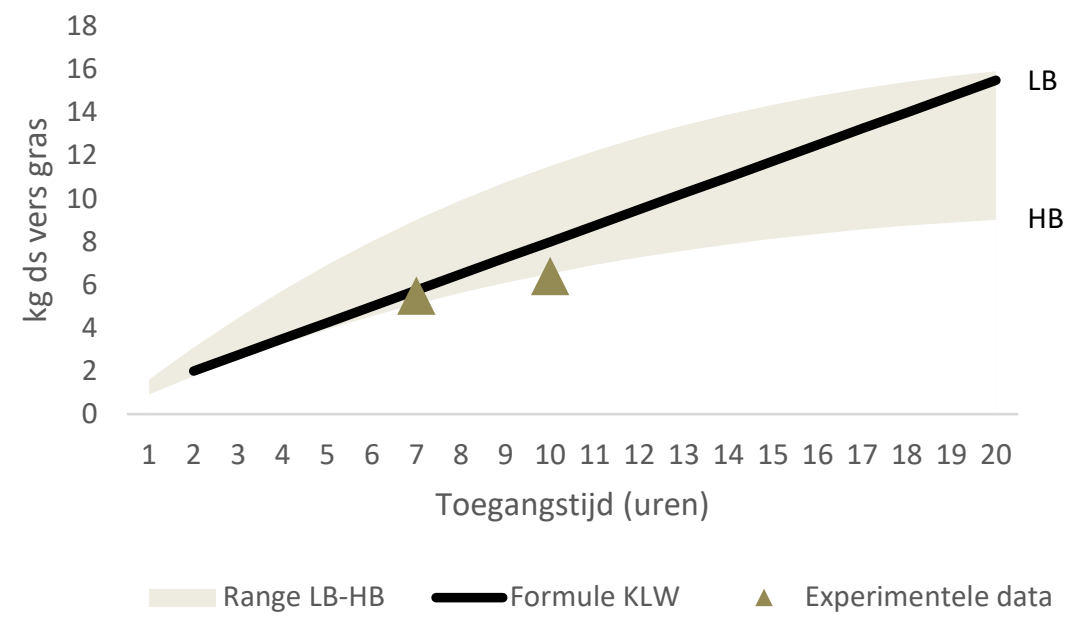

Figuur 6 Effect van toegangstijd tot de wei en bijvoedingsniveau ( $L B$ = laag bijvoedingsniveau en $H B=$ hoog bijvoedingsniveau) op de berekende vers grasopname met opnamesnelheid bij lage bijvoeding volgens Abrahamse (2009) en opnamesnelheid bij hoge bijvoeding volgens (Pérez-Prieto et al., 2011) en de grasopname berekend volgens de huidige formule in de KringloopWijzer. De driehoeken zijn daadwerkelijk gemeten opnames binnen het project Amazing Grazing (Schils et al., 2019).

Figuur 6 laat zien dat de formule voor de KringloopWijzer mooi in de range van berekende grasopnames op basis van opnamesnelheden bij lage bijvoeding volgens Abrahamse (2009) en hoge 
bijvoeding volgens Pérez-Prieto et al. (2011) valt. Op basis van de experimentele data en de range is ook te zien dat de grasopname kan worden overschat bij hoge bijvoedingsniveaus. Aangezien bijvoedingsniveaus vaak ook afnemen met het toenemen van de toegangstijd in de wei zal voor een lagere toegangstijd de HB curve meer kloppen en voor een hogere toegangstijd de LB curve. Zonder extra invoer kunnen experts niet beter bepalen wat de grasopname is dan huidige methode in de KringloopWijzer door de grote range waarin de daadwerkelijke grasopname zich kan bevinden. Met extra gegevensinvoer over grootte van de huiskavel zou de grasopname specifieker bepaald kunnen worden doordat een inschatting gemaakt kan worden van het aanbod van vers gras en/of het bijvoedingsniveau. De grootte van de huiskavel is relatief makkelijk in te schatten en zou waardevol zijn om de grasopname beter in te kunnen schatten. In eerder onderzoek is de grootte van de huiskavel ook geautomatiseerd bepaald middels een GIS-analyse van gegevens van de Gecombineerde Opgave voor alle melkveebedrijven in Nederland (Van den Pol-van Dasselaar et al., 2015).

\subsection{Graskwaliteit}

De verhoudingen tussen de $\mathrm{N}$-, $\mathrm{P}$ - en VEM-gehalten in vers gras en graskuil zoals nu in de KringloopWijzer worden gebruikt (formule 2 en 3) zijn gebaseerd op grasmonsters van Koeien en Kansen bedrijven genomen gedurende de jaren 1999-2015. Een mogelijke benadering om de schatting van de $\mathrm{N}$ - en P-gehalten in de KringloopWijzer te verbeteren is om het moment van weidegang (m.a.w. wanneer in het jaar weiden de koeien) gebruiken om per seizoen. de gehalten te schatten. De (toekomstige) digitale registratie voor de zuivelbedrijven zou hiervoor gebruikt kunnen worden. Een bijkomend voordeel is dat de informatie over de periode van weidegang ook gebruikt kan worden om de grasopname beter in te schatten. Om te toetsen of inzicht in de periode van beweiding de schatting van de graskwaliteit zou verbeteren, is het noodzakelijk om inzicht te krijgen in het verloop van $\mathrm{N}$-, P- en VEM-gehalten van vers gras gedurende het seizoen. Het grasgroeimeetnet onderhoudt een database met graslandgegevens op basis van een meetnet met praktijkbedrijven. Een dergelijk meetnet zou op termijn een rol kunnen spelen bij het beter inschatten van de N-, P- en VEMgehalten van vers gras gedurende het seizoen. Deze data is vooralsnog niet beschikbaar. Verder wordt er op dit moment niet structureel gedurende het seizoen gemeten aan vers graskwaliteit op praktijkbedrijven. Op proefbedrijf de Marke is wel uitvoerig gemeten aan vers graskwaliteit gedurende het seizoen voor meerdere jaren. Deze dataset zou gebruikt kunnen worden voor een eerste inventarisatie, echter met de opmerking dat het hier om één grondsoort op één bedrijf gaat, zodat het lastig is om de resultaten te laten gelden voor alle bedrijven. Ook nieuwe technieken als 'satellietdata' kunnen wellicht op termijn een rol vervullen om meer data te verkrijgen. 


\section{$7 \quad$ Conclusies en aanbevelingen}

Het doel van dit onderzoek was om te verkennen of de opname van vers gras, met bijbehorende $\mathrm{N}$ - en $\mathrm{P}$-gehalten, in de KringloopWijzer beter bepaald kan worden dan de huidige werkwijze. Dit is gedaan op basis van nieuwe inzichten uit onderzoek (literatuur, expertkennis, experimenten). Bij voorkeur zonder extra invoer, maar indien extra invoer nodig is, moet deze minimaal zo goed geborgd zijn als de huidige invoer van de Centrale Database KringloopWijzer (CD KLW).

\section{Conclusies:}

- Op basis van literatuuronderzoek en recente inzichten uit beweidingsonderzoek kan de opname van vers gras, met bijbehorende $\mathrm{N}$ - en P-gehalten, niet beter bepaald worden in de KringloopWijzer voor zover er geen extra invoer mogelijk is in de CD KLW.

- Op basis van de inventarisatie naar mogelijkheden om de opname van vers gras, met bijhorende $\mathrm{N}$ - en $\mathrm{P}$ - gehalten, te verbeteren is gebleken dat dit alleen mogelijk is met extra invoer. Hiertoe zijn de volgende aanbevelingen opgesteld:

\section{Aanbevelingen:}

- Voor de opname van vers gras is de grootte van de huiskavel in relatie tot het aantal weidende koeien (beweidingsintensiteit) naar voren gekomen als optie die inhoudelijk informatie geeft over aanbod van vers gras per koe. Op basis van aanbod van vers gras kunnen experts een inschatting maken van de (maximale) grasopname per koe. Daarnaast is grootte van de huiskavel redelijk makkelijk te registreren en ook objectief vast te stellen.

- De grasopname, maar zeker ook de graskwaliteit, verandert gedurende het seizoen. Het moment van weidegang in het jaar als extra invoer zou de mogelijkheid bieden om bijvoorbeeld onderscheid te maken tussen opname en kwaliteit van vers gras in het voorjaar, zomer en najaar. De (toekomstige) digitale registratie voor de zuivelbedrijven zou hiervoor gebruikt kunnen worden.

- Om de schatting van graskwaliteit verder te kunnen verbeteren is het zinvol om een database met graslandgegevens op basis van een meetnet met praktijkbedrijven te onderhouden. Op deze manier kunnen we meer inzicht verkrijgen in het gemiddelde verloop van graskwaliteit gedurende het seizoen, over jaren heen en voor verschillende regio's.

- Er zijn twee benaderingen mogelijk om extra invoer (i.e. grootte van de huiskavel en moment van weidegang) te gebruiken ter verbetering van het schatten van de grasopname en bijbehorende gehalten. Beide benaderingen zijn gebaseerd op een combinatie van kennis uit literatuur en expert opinie. De benaderingen zijn:

1. Op basis van de extra invoergegevens wordt een klasseindeling gemaakt en deze indeling wordt gebruikt om de bandbreedte aan te geven waarbinnen de grasopname zich in een bepaalde klasse kan bewegen.

2. Op basis van de extra invoergegevens wordt een indeling gemaakt in klassen met vaste waardes voor grasopname afhankelijk van het aantal uren weidegang

Toetsing van deze benaderingen voor de KringloopWijzer kan met behulp van data van Koeien \& Kansen bedrijven.

Tot slot willen wij ook de relevantie van de perceptie van veehouders over de hoogte van de grasopnames en effecten hiervan op de $\mathrm{N}$ - en P-excretie benadrukken. Onze aanbeveling is doelgerichte communicatie om het belang van het invoeren van het juiste aantal uren weidegang (of een andere benadering om grasopname en graskwaliteit in te schatten) in het juiste perspectief te plaatsen. Hiervoor is het noodzakelijk om breed inzichtelijk te maken wat de effecten zijn van het niveau van grasopname op alle relevante duurzaamheidsaspecten op het melkveebedrijf. Hierbij zijn ook andere factoren zoals eiwit van eigen land, broeikasgasemissies en andere emissies van belang. Analyse van KringloopWijzer data is hierbij aan te bevelen om tot dit inzicht te komen en heldere boodschappen te formuleren en te communiceren. 


\section{Literatuur}

Abrahamse, P. A. 2009. Feeding and Grazing Management for Dairy Cattle: Opportunities for Improved Production. PhD thesis. Wageningen University, Wageningen.

Andriamandroso, A. L. H., J. Bindelle, B. Mercatoris, en F. Lebeau. 2016. A review on the use of sensors to monitor cattle jaw movements and behavior when grazing. Biotechnologie, Agronomie, Société et Environnement 20.

Baumont, R., S. Prache, M. Meuret, en P. Morhand Fehr. 2000. How forage characteristics influence behaviour and intake in small ruminants: a review. Livestock Prod. Sci. 61:15-28.

Chilibroste, P., M. J. Gibb, P. Soca, en D. A. Mattiauda. 2015. Behavioural adaptation of grazing dairy cows to changes in feeding management: do they follow a predictable pattern? Anim Prod Sci 55:328338. doi.org/http://dx.doi.org/10.1071/AN14484.

Decruyenaere, V., A. Buldgen, en D. Stilmant. 2009. Factors affecting intake by grazing ruminants and related quantification methods: a review. Biotechnologie Agronomie Societe Et Environnement 13:559-573.

Decruyenaere, V., E. Froidmont, N. Bartiaux-Thill, A. Buldgen, en D. Stilmant. 2012. Faecal near-infrared reflectance spectroscopy (NIRS) compared with other techniques for estimating the in vivo digestibility and dry matter intake of lactating grazing dairy cows. Animal Feed Science and Technology 173:220-234. doi.org/10.1016/j.anifeedsci.2012.02.005.

Delagarde, R., P. Faverdin, C. Baratte, en J. L. Peyraud. 2011. GrazeIn: a model of herbage intake and milk production for grazing dairy cows. 2. Prediction of intake under rotational and continuously stocked grazing management. Grass Forage Sci. 66:45-60. doi.org/10.1111/j.1365-2494.2010.00770.x.

Delagarde, R., S. Prache, P. D'-Hour, en M. Petit. 2001. Ingestion de I'herbe par les ruminants au paturage.; Grass intake by grazing ruminants. Fourrages 166:189-212.

Dove, H. en R. W. Mayes. 1996. Plant wax components: A new approach to estimating intake and diet composition in herbivores. Journal of Nutrition 126:13-26.

Hellwing, A. L. F., P. Lund, M. R. Weisbjerg, F. W. Oudshoorn, L. Munksgaard, en T. Kristensen. 2015. Comparison of methods for estimating herbage intake in grazing dairy cows. Livest Sci 176:61-74. doi.org/http://dx.doi.org/10.1016/j.livsci.2015.01.013.

Holster, H., M. Plomp, M. Timmerman, en M. d. Haan. 2015. Quick scan naar de invloed van moeilijk controleerbare invoergegevens van de KringloopWijzer. Wageningen UR (University \& Research centre) Livestock Research, Wageningen Pages: $59 \mathrm{blz}$.

Oenema, J., L. B. Šebek, J. J. Schröder, J. Verloop, M. H. A. De Haan, en G. J. Hilhorst. 2017a. Toetsing van de KringloopWijzer; Gemeten en voorspelde stikstof- en fosfaatproducties van mest en gewas. Wageningen Research. Pages: 80 blz.

Oenema, J., J. Verloop, J. De Boer, B. Rutgers, en S. L. G. E. Burgers. 2017b. Onzekerheids- en gevoeligheidsanalyse van de door de KringloopWijzer voorspelde stikstof en fosfaatproducties van mest en gewas.

Oudshoorn, F. W., C. Cornou, A. L. F. Hellwing, H. H. Hansen, L. Munksgaard, P. Lund, en T. Kristensen. 2013. Estimation of grass intake on pasture for dairy cows using tightly and loosely mounted diand tri-axial accelerometers combined with bite count. Computers and Electronics in Agriculture 99:227-235. doi.org/10.1016/j.compag.2013.09.013.

Pérez-Prieto, L. A., J. L. Peyraud, en R. Delagarde. 2011. Substitution rate and milk yield response to corn silage supplementation of late-lactation dairy cows grazing low-mass pastures at 2 daily allowances in autumn. J. Dairy Sci. 94:3592-3604. doi.org/https://doi.org/10.3168/jds.2011-4216.

Peyraud, J. L. en A. González-Rodríguez. 1999. Relations between grass production, supplementation and intake in grazing dairy cows. Pages 269-282 in Proc. Grassland Science in Europe 5.

Roca-Fernández, A. I. en A. González-Rodríguez. 2017. External validation of the GrazeIn model of pasture dry matter intake and milk yield prediction for cows managed at different calving dates and stocking rates. Spanish Journal of Agricultural Research 15:e0608. doi.org/10.5424/sjar/2017154-10380.

Rombach, M., K. H. Südekum, A. Münger, en F. Schori. 2019. Herbage dry matter intake estimation of grazing dairy cows based on animal, behavioral, environmental, and feed variables. J. Dairy Sci. 102:2985-2999. doi.org/https://doi.org/10.3168/jds.2018-14834.

Schils, Philipsen, Hoekstra, G. Holshof, Zom, Hoving, Reenen, Stienezen, Klootwijk, v. Werf, Sebek, v. Eekeren, v. Dixhoorn, en A. van den Pol-van Dasselaar. 2019. Amazing Grazing: A Public and Private Partnership to Stimulate Grazing Practices in Intensive Dairy Systems. Sustainability 11:5868. doi.org/10.3390/su11205868. 
Schröder, J. J., L. B. Šebek, J. Oenema, J. G. Conijn, T. Vellinga, en J. De Boer. 2019. Rekenregels van de KringloopWijzer 2018; Achtergronden van BEX, BEA, BEN, BEP en BEC: actualisatie van de 2017versie Wageningen Research, Wageningen. Pages: 128 blz.

Šebek, L., H. v. Schooten, B. Bassa, en C. v. Dijk. 2018. KringloopWijzer nader bekeken; Toepasbaarheid KringloopWijzer voor niet-gemiddelde melkveebedrijven waaronder bedrijven met extensievere bedrijfsvoering. Wageningen Livestock Research. Pages: $42 \mathrm{blz}$.

Van den Pol-van Dasselaar, A., P. W. Blokland, T. J. A. Gies, G. Holshof, M. H. A. D. Haan, H. S. D. Naeff, en P. Philipsen. 2015. Beweidbare oppervlakte en weidegang op melkveebedrijven in Nederland (Grazing platform and grazing on dairy farms in the Netherlands). Wageningen UR (University \& Research centre) Livestock Research, Livestock Research, Wageningen.

Zom, R. L. G. en G. Holshof. 2011. GrazeVision: A versatile grazing decision support model. Pages 226-228 in Proc. 16th EGF Symposium, Grassland Farming and Land Management Systems in Mountainous Regions. Organising Committee of the 16th Symposium of the European Grassland Federation 2011 and Agricultural Research and Education Centre (AREC) Raumberg-Gumpenstein, Austria, Raumberg-Gumpenstein, Austria. 


\section{Bijlage 1 Lijst met stakeholders die betrokken zijn bij dit project}

De werkzaamheden en de (tussen)resultaten zijn afgestemd met de stuurgroep 'Wetenschappelijke doorontwikkeling KringloopWijzer' en de klankbordgroep rondom de BEP pilot.

De stuurgroep 'Wetenschappelijke doorontwikkeling KringloopWijzer':

Han Swinkels, ZuivelNL

Marissa Giessen. LNV (tot 1 sep'19) $^{\prime}$

Cees Verbogt, LNV (vanaf 1 sep'19) $^{\prime}$

Bregje van Erve, Duurzame Zuivelketen

Willem Koops, ZuivelNL

Henk Schoonvelde, LTO Melkveehouderij (voorzitter; tot 1 sep'19)

Jos Verstraten, LTO Melkveehouderij (voorzitter; vanaf 1 sep'29)

Arjan van Dijk, Nevedi

Koos Verloop, Wageningen Plant Research

Mona van Spijk, NZO

Willemien van de Kandelaar, LTO Melkveehouderij

Michel de Haan, Wageningen Livestock Research

De klankbordgroep rondom de BEP-pilot:

Han Swinkels, ZuivelNL (voorzitter)

Johan Temmink, ForFarmers

Gerrit Schilstra, Agrifirm Exlan

Barend Meerkerk, PPP Agro Advies

Willemien van de Kandelaar, LTO Melkveehouderij

Bregje van Erve, Duurzame Zuivelketen

Mona van Spijk, NZO

Jaap Gielen, VLB

De internationale en nationale experts, inclusief de deelnemers aan de workshop hebben een bijdrage geleverd aan de inventarisatiefase waarbij een groslijst is gemaakt met mogelijk benaderingen om de berekening van de opname van vers gras, met bijbehorende $\mathrm{N}$ - en P-gehalten, in de KringloopWijzer te verbeteren.

Internationale experts:

Carsten Malisch en Friedhelm Taube, Universiteit Kiel, Duitsland

Martin Elsäßer, Grünlandwirtschaft Aulendorf, Duitsland

Henri Kohnen, Lycée d'Agricole, Luxemburg

Alex de Vliegher, ILVO, België

Deirdre Hennessy, Teagasc, Ierland

Luc Delaby, INRA, Frankrijk

Nationale experts:

Gerjan Hilhorst, PRC de Marke

Tom Keuper, veehouder

Kees-Jaap Hin, Stichting Weidegang

Jacob van Vliet, LNV

Gerard Polinder, De Heus Voeders

Deelnemers workshop:

Han Swinkels, ZuivelNL 
Bas Bassa, Dirksen Management Support

Leo Tjoonk, Agrifirm

Jaap Gielen, Countus (namens VLB)

Niek Konijn, CONO Kaasmakers

Gerjan Hilhorst, KTC de Marke

Gertjan Holshof, Wageningen Livestock Research 


\section{Bijlage 2 Mail naar internationale experts}

Dear........,

In the Netherlands every dairy farmer has to account for the flows of $\mathrm{N}$ and $\mathrm{P}$ on the farm. It is obligatory to fill in ANCA each year for this purpose (Annual Nutrient Cycling Assessment) https://www.wur.nl/en/article/Annual-Nutrient-Cycling-Assessment.htm. ANCA calculates the intake of fresh grass currently working to improve the estimates of fresh grass intake of dairy cows for this ANCA. It would be good to learn from experiences in other countries ANCA now calculates the intake of pasture grass from a formula in which the cows take up $1 \mathrm{~kg}$ DM of fresh grass per hour during the first two hours of outdoor grazing and $0.75 \mathrm{~kg}$ DM of pasture grass per hour during the remaining hours. This quantity is then adjusted in a calculated proportion to the quantity of grass silage and maize silage consumed (stocks/silage heaps are measured for this purpose). The levels of $N$ and $P$ in the pasture grass are made dependent on the levels in the silage pits. Advantages of this method are the simplicity and the lack of additional measurements in the field. However, results are not always logical, therefore this method and the results of this calculation lead to practical discussions.

_Question to you_

Because of your expertise, we would appreciate it if you could answer the following two questions:

- What's your opinion on the method used in ANCA?

- If you would have the opportunity to develop a tool like ANCA, which method or formula or procedure would you use to reliably estimate grass intake of grazing dairy cows on a commercial dairy farm?

We would really appreciate if you could share your ideas on this issue. We will ask this question to relevant people in the Netherlands and to a limited number of scientists that work in different countries.

Thanks in advance, 


\section{Bijlage 3 Mail naar nationale experts}

Beste.........,

Vanuit een project, gefinancierd door ZuivelNL, zijn we aan het verkennen of de bepaling in de KringloopWijzer van de opname van vers gras, met bijbehorende gehalten, verbeterd kan worden. Nu berekent de KringloopWijzer de opname van vers gras vanuit een formule, waarbij de koeien de eerste twee uur van weidegang $1 \mathrm{~kg}$ ds vers gras per uur opnemen en de overige uren $0,75 \mathrm{~kg}$ ds vers gras per uur. Vervolgens wordt deze hoeveelheid bijgesteld in een berekende verhouding met de verbruikte (gemeten voorraden) hoeveelheid graskuil en maiskuil. De gehaltes van $\mathrm{N}$ en $\mathrm{P}$ in het vers gras zijn afhankelijk gesteld van de gehaltes in de aangelegde graskuilen. Deze werkwijze en de uitkomsten van deze berekening leiden tot discussie in de praktijk.

Via een inventarisatie zullen wij via meerdere routes input vragen van experts/betrokkenen rondom grasopname KringloopWijzer, beginnend met een korte enquête. De reacties hierop zullen we ook gebruiken als input voor een workshop rondom dit thema. Mogelijk zal dit proces leiden tot een nieuwe werkwijze om de grasopname in de KringloopWijzer te bepalen. Vanwege uw expertise zouden wij het erg op prijs stellen als $u$ de volgende twee vragen wilt beantwoorden:

- Hoe zou u de grasopnameschatting (en gehaltes van N en P) binnen het huidige frame van de KringloopWijzer willen veranderen?

- Als u opnieuw zou mogen beginnen met een grasopnameschatting in de KringloopWijzer (met huidige kennis), hoe zou u het dan aanpakken?

Alvast hartelijk dank, 


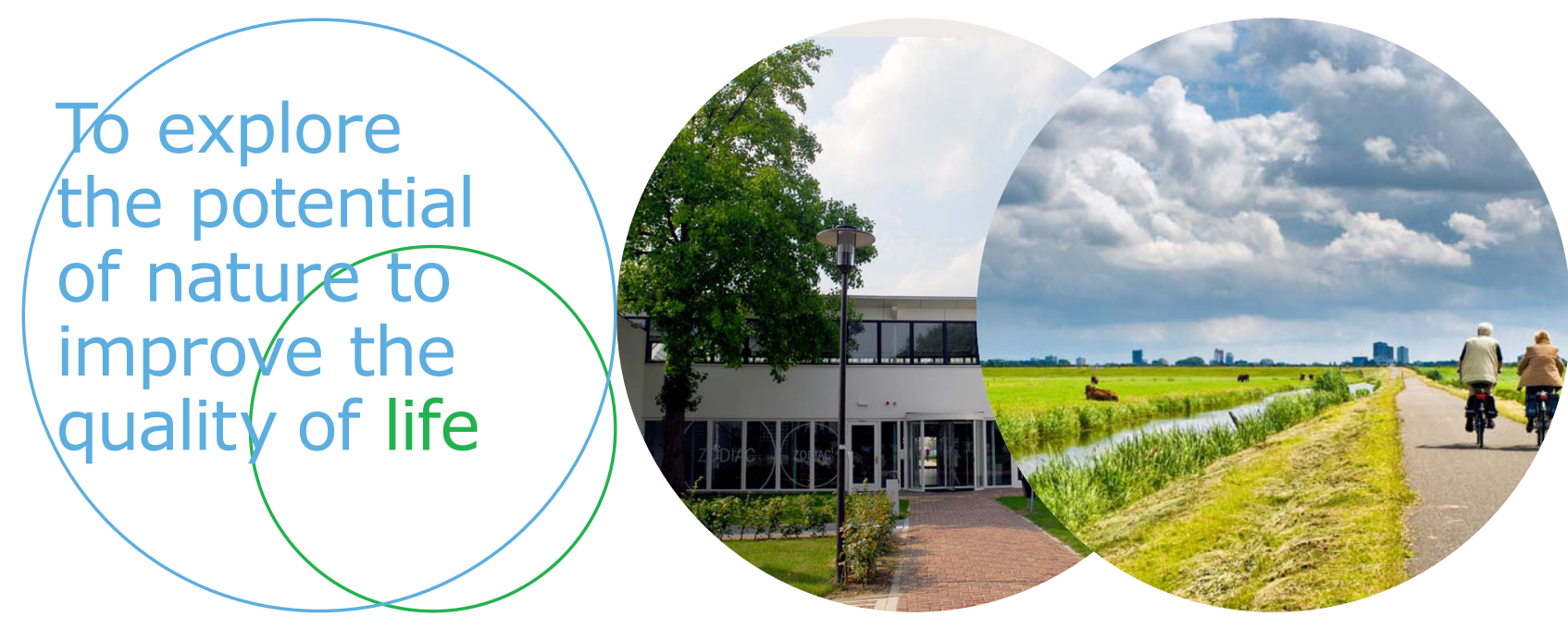

Wageningen Livestock Research Postbus 338

$6700 \mathrm{AH}$ Wageningen

T 0317483953

E info.livestockresearch@wur.nl www.wur.nl/livestock-research
Wageningen Livestock Research ontwikkelt kennis voor een zorgvuldige en renderende veehouderij, vertaalt deze naar praktijkgerichte oplossingen en innovaties, en zorgt voor doorstroming van deze kennis. Onze wetenschappelijke kennis op het gebied van veehouderijsystemen en van voeding, genetica, welzijn en milieu-impact van landbouwhuisdieren integreren we, samen met onze klanten, tot veehouderijconcepten voor de $21 \mathrm{e}$ eeuw.

De missie van Wageningen University \& Research is 'To explore the potential of nature to improve the quality of life'. Binnen Wageningen University \& Research bundelen 9 gespecialiseerde onderzoeksinstituten van Stichting Wageningen Research en Wageningen University hun krachten om bij te dragen aan de oplossing van belangrijke vragen in het domein van gezonde voeding en leefomgeving. Met ongeveer 30 vestigingen, 6.500 medewerkers en 10.000 studenten behoort Wageningen University \& Research wereldwijd tot de aansprekende kennisinstellingen binnen haar domein. De integrale benadering van de vraagstukken en de samenwerking tussen verschillende disciplines vormen het hart van de unieke Wageningen aanpak. 